\title{
Gelation of Styrene-Acrylonitrile Copolymer via Cyclodiborazane Formation
}

\author{
Nobuhiro IDE ${ }^{* 1}$, Asahiro OGUCHI ${ }^{* 1}$, Yoshinobu TsuJII ${ }^{* 1}$, Takeshi FUKUDA ${ }^{* 1}$, \\ Takeaki MıYАMOTO $^{* 1}$, Nobuhiro HIgASHIDA ${ }^{* 2}$, and Yoshiki CHUJO ${ }^{* 2}$ \\ ${ }^{* 1}$ Institute for Chemical Research, Kyoto University, Uji, Kyoto 611, Japan \\ ${ }^{* 2}$ Division of Polymer Chemistry, Graduate School of Engineering, Kyoto University, Yoshida, Sakyo-ku, Kyoto 606-01, Japan
}

An azeotropic copolymer of styrene and acrylonitrile was studied with its gelation process via the cyclodiborazane formation between thexylborane (TB) and the cyano groups of the copolymer in 2methoxyethyl ether solution. The concentrations of TB, cyano groups, and iminoborane were in situ determined by infrared spectroscopy. In addition, the number density of cross-links, i.e., the concentration of cyclodiborazane was quantitatively estimated after the treatment with methanol, which reacts with the B-H groups of TB and iminoborane without decomposition of cyclodiborazane. The number of cross-links was found to increase with reaction time, reaching about 3 per chain at the gel point for the copolymer used in this study.

Key words: styrene-acrylonitrile copolymer / thexylborane / infrared spectroscopy / gelation / cross-link density

\section{シクロジボラザン形成によるスチレンーアクリロニトリル共重合体のゲル化}

\author{
井出伸弘 ${ }^{*_{1}}$ - 小口朝弘 ${ }^{*_{1}} \cdot$ 辻井敬亘 $^{*_{1}}$ - 福田 猛 ${ }^{*_{1}} \cdot$ 宮本武明 ${ }^{*_{1}} \cdot$ 東田進弘 ${ }^{*_{2}}$. 中條善樹 ${ }^{*_{2}}$ \\ (原稿受理：1997年6月30日)
}

\section{1. 緒言}

直鎖状高分子に化学的あるいは物理的架橋を導入すると、その 溶液はしばしばゲル化する。この現象の詳細な理解には、架橋形 成機構の解明に加えて、ゲル化に必要な最小の架橋数（臨界架橋 密度）と高分子の分子特性（分子量、分子鎖の広がり等）や濃度 との相関を明らかにすることが必要不可欠である。

Flory-Stockmayerの古典的ゲル化理論（FS理論）によると、分子 量的に均一な一次高分子(架橋前の高分子)の臨界架橋密度は、一 分子あたり 0.5 個である。一方、この問題に関する実験的研究はこ れまでにも多く行われているが1.2)、ほとんどの場合、実験值は理 論值に比して非常に大きい。この差は、FS理論で無視されている 分子内架橋の形成に起因寸ると考えられ、事実、分子内架橋が少 ないと考えられる系ではFS理論と比較的良い一致が認められて いる3-5)。しかし、臨界架橋密度と分子特性や高分子濃度との関係 を系統的に調べた研究は数少ない。

本研究ではスチレン $(\mathrm{St})$ とアクリロニトリル $(\mathrm{AN})$ の共重合体を 用い、溶液中でのテキシルボラン $(\mathrm{TB})$ とのヒドロボレーション反 応6-8)によるゲル化について検討した。この反応は Scheme 1 に示 すように側鎖シアノ基と TBとの反応によってイミノボランが生

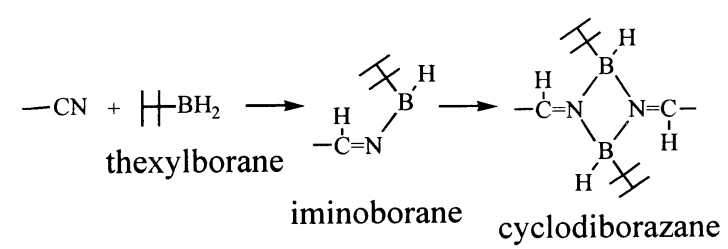

Scheme 1 Formation of cyclodiborazane.

${ }^{* 1}$ 京都大学化学研究所 $\overline{7} 611$ 京都府宇治市五ヶ庄

*2 京都大学工学研究科高分子化学専攻 $\overline{7} 606-01$ 京都市左京区吉田本町
成し、次いでその二量化によってB-N四員環のシクロジボラザン (架橋点) が形成されることにより溶液がゲル化するものである。 本系を用いる利点として、赤外吸収 (IR) 分光法により架橋密度 をその場(in situ)測定しうる可能性があること、仕込みモノマー組 成を変えることにより共重合組成すなわち架橋可能サイトの密 度が異なる共重合体が得られ、さらに“リビング”ラジカル共重 合法により分子量の異なる比較的分子量分布の狭い共重合体を 容易に得ることができること辛が挙げられる。つまり本系は、柔 軟な直鎖状高分子のゲル化過程を系統的に研究するための優れ たモデル系となる可能性を有する。ここではシアノ基を比較的多 く有寸る低分子量の高分子 (AN分率38mol.-\%、Mn=12,000)を用 いてIR法による架橋数の定量の可能性を検討した。また、ゲル化 に必要な反応条件（ポリマー濃度、TB濃度）や臨界架橋密度に関 寸る予備的な研究も行った。

\section{2. 实験}

\section{$2 \cdot 1$ 試料}

St-ANランダム共重合体は窒素酸化物を利用するラジカル重合 法により得た。蒸留精製したStとANのアゼオトロープ混合物 (AN 分率 $38 \mathrm{~mol}-\%)$ に過酸化ベンゾイル $(70 \mathrm{mmol} / \mathrm{L})$ およびTEMPO (2,2,6,6-テトラメチルピペリジニル-1-オキシ, $84 \mathrm{mmol} / \mathrm{L})$ を加え脱 気封管後、 $95^{\circ} \mathrm{C}$ で 3 時間、 $125^{\circ} \mathrm{C}$ で 5 時間反応させた。再沈精製 により得られたポリマーの数平均分子量 $\mathrm{M}_{\mathrm{n}}$ は 12,000 、重量平均分 子量 $\mathrm{M}_{\mathrm{w}}$ は19,000であった(PSt換算、GPC測定)。 ${ }^{1} \mathrm{H}-\mathrm{NMR}$ よび元 素分析によりポリマーの組成が仕込み組成と同じであることを 確認した。また、2-メトキシエチルエーテル中での固有粘度 $[\eta]$ をウベローデ型粘度計で測定し、重なり濃度 $\mathrm{C}^{*} \approx[\eta]^{-1}$ の関係を用 いてC* $=70 \mathrm{~g} / \mathrm{L}$ 見積った。テキシルボランは文献10に従って合 成し、減圧蒸留により精製した。

$2 \cdot 2$ 試料溶液の調製と反応

試料溶液の調製と反応は乾燥窒素䨌囲気下で行った。溶媒には 
脱水・窒素置換された 2 -メトキシエチルエーテルを用いた。反応 は、所定濃度に調製したポリマー溶液を激しく攪找しながら所定 量のテキシルボランを滴下し、室温で放置することにより行った。 $2 \cdot 3$ 試料溶液のゲル化

試験管倒置法により決定した。すなわち $2 \cdot 2$ で調製した試料 溶液を直径 $15 \mathrm{~mm}$ のガラス管に封入した後一定時間ごとに倒置し、 溶液が流れる場合をゾル、流れない場合をゲルと定義した。

\section{$2 \cdot 4$ I Rスペクトル測定}

溶液試料の測定にはKRS-5を空板とした光路長 $0.5 \mathrm{~mm}$ の溶液セ ルを用いた。2-メトキシエチルエーテルは、本研究で定量に用い た波数領域 $\left(2200 \sim 2600 \mathrm{~cm}^{-1}\right)$ で比較的透明であり測定に適して いた。また、固体試料の測定は $\mathrm{KBr}$ 用いた錠剤法により行った。

\section{3. 結果及び考察}

\section{3・ 1 | Rスペクトル測定}

図 1 (A)に各反応時間に扔ける溶質（ポリマー、TB及び反応生 成物）のIRスペクトルを示す（[polymer] = 14.9wt.-\%、[TB] =

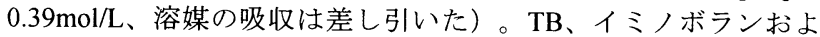
びポリマーのシアノ基に由来する吸収がそれぞれ $2517 \mathrm{~cm}^{-1}$ (B-H 伸縮振動）、2452 $\mathrm{cm}^{-1}$ (B-H伸縮振動）、2237 $\mathrm{cm}^{-1}$ (CN伸縮振動) に独立して観測され、これらの吸光度より反応溶液中の各成分の 濃度変化を直接測定することが可能であった。反応の進行ととも

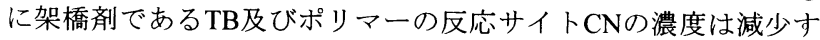
るのに対して、反応中間体イミノボランの濃度は初期には増大し、 TBが完全に消費されると減少に転じることが判明した。

また架橋点シクロジボラザンの吸収は、ゲル化後さらに反応を 進行させることによりその場定量が可能である。しかし、ゲル化 点近傍での吸収は小さな肩として観測されるのみであり、さらに $2 つ の$ 吸収が近傍に存在する（図中＊：帰属の詳細は不明。ただ し、反応開始直後に現れ反応の進行とともに減少し、TBの消失と ともに消失した）。このためゲル化点近傍でのその場定量は困難 であった。

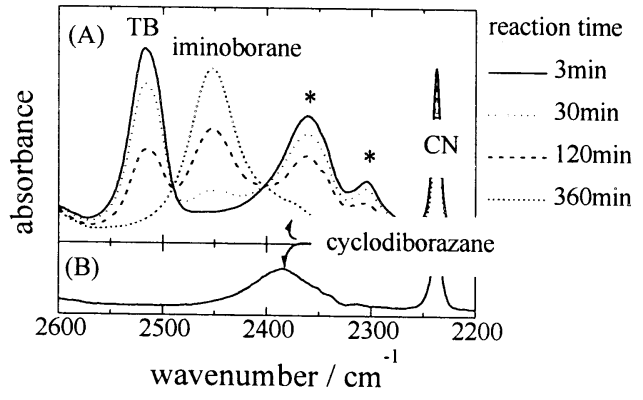

Fig. 1 (A) Time evolution of IR spectra.

(B) Cyclodiborazane absorption.

\section{$3 \cdot 2$ 架橋数の定量}

TBおよびイミノボランのB-Hはアルコール等と反応して容易 に消失するのに対して、本反応での架橋点であるシクロジボラザ ンのB-Hは空気、水等に対して安定である(の) そこで、反応系にメ タノールを添加・乾燥後、錠剂法により IRスペクトルを測定した。 図1(B)に示すように、TBおよびイミノボラン由来の吸収に加え て前述の吸収 (図中*) も完全に消失し、シクロジボラザンのB-H 伸縮振動に帰属される吸収6.7)のみが明瞭に観測された。この手法 を、ゲル化後さらに反応が進行しシクロジボラザンのその場定量 が可能な試料について試みたところ、シクロジボラザン由来の吸 収は前述の処理によってほとんど減少しないことが確認された。 寸なわち、架橋点由来の吸収のみを定量的に観測することが可能 であり、ポリマー中のスチレン芳香環由来の吸収 $\left(1950 \mathrm{~cm}^{-1}\right)$ で規 格化することで架橋点濃度を算出することができた。

\section{$3 \cdot 3$ 試料溶液のゲル化及び臨界架橋数}

種々のポリマー濃度 [polymer] 及びテキシルボラン濃度 [TB] の試料溶液についてゲル化するか否かを観測した。ポリマー濃度

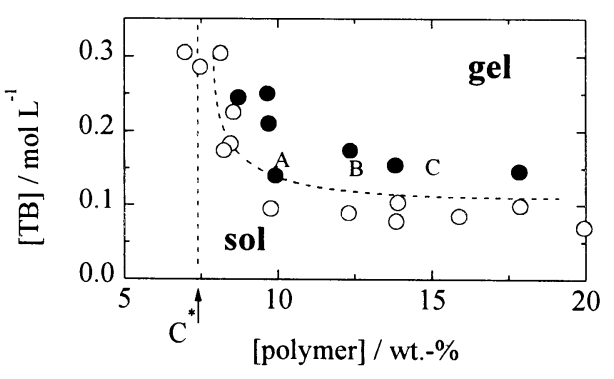

Fig. 2 Sol-gel diagram $(t=24 h)$.

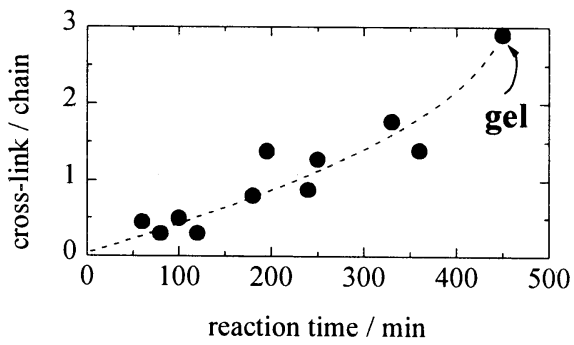

Fig. 3 Time evolution of cross-link density.

あるいはテキシルボラン濃度が高いほど試料溶液はより短時間 でゲル化した。図 2 に、24時間以内にゲル化した試料を黒丸で、 ゲル化しなかった試料を白丸で示す。ゲル化が観測されたのはす ペてポリマー濃度が重なり濃度 $\mathrm{C}^{*}$ 以上の溶液であった。C范以下の 溶液では、高分子鎖の重なりが充分でないために分子内での架橋 が優先的に形成され、ゲル化に必要な数の分子間架橋が形成され ないためであると考えられる。

なお、上記の手法により試料溶液（図 2 中 C、 [polymer] = $14.9 \mathrm{wt} .-\% 、[\mathrm{~TB}]=0.16 \mathrm{~mol} / \mathrm{L})$ について各反応時間における高分子 鎖 1 本あたりの架橋数を算出したところ、架橋数は時間とともに 増加し、ゲル化点では約 3 個と見積られた（図 3 ）。また、ゲル 化直後の架橋数の定量を図 2 中 A、B 点についても行ったところ、 高分子鎖 1 本当たりの架橋数は同じく約 3 個と見積られた。FS理 論によると本試料のゲル化に必要とされる架橋数は約 0.3 個であ りここで得られた值とは10倍程度の差が見られ、この条件下では 分子内架橋の寄与が大きいことが示唆された。

\section{4. 結論}

本研究で用いたスチレンーアクリロニトリル共重合体/テキ シルボラン系では反応系中又は精製後の試料について、高分子鎖 に導入された架橋数のIRスペクトルによる定量が可能であった。 今後この研究を、臨界架橋密度と反応場の特性に関する系統的な 研究一展開しうるものと考えられる。

\section{参考文献}

1) Schmidt M, Burchard W, Macromolecules, 14, 370 (1981).

2) Mrkvickova L, Kratochvil P, J. Polym. Sci., Polym. Phys. Ed., 19, 1675 (1981)

3) Sato T, Tsujii Y, Fukuda T, Miyamoto T, Macromolecules, 25, 3890; 5970 (1992).

4) Ide N, Tsujii Y, Fukuda T, Miyamoto T, Macromolecules, 29, 3851 (1996).

5) Ide N, Fukuda T, Macromolecules, 30 (No.14) (1997).

6) Chujo Y, Tomita I, Saegusa T, Macromolecules, 27, 6714 (1994).

7) Chujo Y, Tomita I, Saegusa T, Polym. Bull., 31, 553 (1993).

8) Chujo Y, Higashida N, Polym. Prepr., Jpn., 44, 1730 (1995).

9) Fukuda T, Terauchi T, Goto A, Tsujii Y, Miyamoto T, Shimizu Y, Macromolecules, 29, 3050 (1996).

10) Brown HC, Mandal AK, Kulkarni SU, J. Org. Chem., 42, 1392 (1977). 